\title{
Pro-Cyclical Regulation and its Consequences in the Credit Crisis ${ }^{1}$
}

Vytautas Snieska, Prof. Dr.

Department of Economics and International Trade Kaunas University of Technology, Lithuania Email: vytautas.snieska@ktu.It

Ruta Masteikiene, Dr.

Department of Economics and International Trade Kaunas University of Technology, Lithuania Email: ruta.masteikiene@ktu.It

Vitalija Venckuviene, Dr.

Department of Economics and International Trade Kaunas University of Technology, Lithuania Email: vitalija.venckuviene@ktu.It

Gitana Valodkiene, Dr.

Department of Economics and International Trade Kaunas University of Technology, Lithuania Email: gitana.valodkiene@ktu.It

Doi:10.5901/mjss.2013.v4n9p602

\section{Abstract}

As it is widely agreed in modern scientific literature, governments can influence and amortize the consequences of business cycles to national economies. Grounding on the New-Keynesian point of view the best way of doing it, is implementing the counter-cyclical fiscal policy, i.e. in times of economic slow-down government expenditures and overall tax level diminish and in the period of economic growth government expenditures and taxes simultaneously increase. However, this kind of fiscal policy is subject to adoption not in all countries. The analysis of scientific literature revealed, that economically weaker countries due to various financial limitations are forced to implement the opposite of the counter-cyclical policy - the procyclical policy, which in times of economic slow-down accelerates the negative effects and in most cases results in credit crisis. The aim of the article is to reveal and analyze the core consequences of credit crisis if the country adopts a pro-cyclical strategy. Those include: congelation of all types of credits, difficulties for businesses to obtain credits; declining values in real estate and contraction of the whole construction sector; high loss of property rights (foreclosure) rates and default rates on credits; diminishing consumption of households and businesses; numerous close-downs of small and medium enterprises (SMEs); rise in unemployment; growing emigration, brain-drain and etc. Conducting the analysis of consequences of credit crisis in pro-cyclical economies the methods of comparative analysis and systematization of scientific literature and statistical data were employed.

Keywords: credit crisis, pro-cyclical regulation, economic downturn, unemployment, emigration

\section{Introduction}

The economic crisis of 2008 has raised countless discussions both in business and academia on the government role in driving the countries' economies through the economic cycles. It is generally agreed that the correct fiscal policy adopted can mitigate the negative effects of the economic downturns, which are a natural part of the economic cycle. In recent decades various regulation policies meant to control the consequences of business cycles have become of great

1 This research is funded by a grant (No. IEP-01/2012) from the Research Council of Lithuania. 
importance. The inevitable impacts of globalization processes, spread of crisis effects across markets and entire continents are growing at a geometrical progression. Secondly, stabilization policies effectiveness varies greatly in different countries. Some countries manage to stabilize the business cycle negative effects quite easily, while in other countries, the stabilization process is long and complicated. Thirdly, policies adopted in the European Union countries for stabilizing the business cycle implications are particularly significant because their monetary policies are restricted. The core aim of the article is to reveal and analyze the core consequences of credit crisis if the country (due to specific reasons) adopts a pro-cyclical strategy. Conducting the analysis of consequences of credit crisis in countries pro-cyclical economies the methods of comparative analysis and systematization of scientific literature and statistical data were employed.

\section{The essence of cyclical regulation}

Modern scientific literature on the subject proposes a unified approach that the correct fiscal policy can help to stabilize the economy while maintaining the aggregate demand and private sector revenue during the economic downturn, and regulate the economic activity in periods of strong economic growth. Pro-cyclical a-cyclical and counter-cyclical regulations have been subject to analysis in a number of economic theories and schools of thought. Table 1 below reveals the essence of pro-cyclical, counter-cyclical and a-cyclical regulations as options for fiscal policy in the context of business cycle theory.

Table 1. Pro-cyclical and counter-cyclical regulation

\begin{tabular}{|l|l|}
\hline \multicolumn{2}{|l|}{ Business cycle theory } \\
\hline Pro-cyclical regulation & $\begin{array}{l}\text { Any economic quantity that is positively correlated with the overall state of } \\
\text { the economy. That is, any quantity that tends to increase when the overall economy is } \\
\text { growing is classified as pro-cyclical. }\end{array}$ \\
\hline $\begin{array}{l}\text { Counter-cyclical } \\
\text { regulation }\end{array}$ & $\begin{array}{l}\text { Any economic quantity that is negatively correlated with the overall state of the economy is } \\
\text { said to be counter-cyclical. That is, quantities that tend to increase when the overall } \\
\text { economy is slowing down are classified as 'countercyclical'. }\end{array}$ \\
\hline A- cyclical regulation & $\begin{array}{l}\text { Any economic quantity that does not correlate with the overall state of the economy. That is, } \\
\text { any quantity is independent whether the economy is growing or slowing down. }\end{array}$ \\
\hline
\end{tabular}

Sources: Abel \& Bernanke (2001),

However, in economic policy context the pro-cyclical regulation ${ }^{2}$ refers to any aspect of economic policy that magnifies fluctuations in economics and finance. Pro-cyclical fiscal policy occurs at a higher (lower) level of government spending and lower (higher) tax rates level in good (bad) times. This policy is known as pro-cyclical due to its tendency to strengthen the business cycle (i.e., fiscal policy is expansionary in good times and damping at bad times). It is important to emphasize, that the effects of the single Eurozone interest rates on the comparatively high-inflation states in the Eurozone territory is considered to be pro-cyclical and leads to very low interest rates in the growth period which only accelerates economic booms and real estate price bubbles whose sudden busts augments the downturns. ${ }^{3}$

Counter-cyclical policy occurs at lower (higher) level of government spending and higher (lower) tax rates at the level of good (bad) times. Such policy is known as counter-cyclical because it seeks to stabilize the business cycle effects (i.e., fiscal policy is tightening the economy in good times and expanding in bad times). In the case of countercyclical policy, the tax rates are high in good times and low in bad times, which means that the income tax (calculated as the tax rate times the tax base) and the primary balance (calculated as revenues from taxes minus government spending (excluding interest payments)) has a positive correlation with the business cycle, since the revenue from the tax

\footnotetext{
${ }^{2}$ It is noteworthy to mention that the financial regulatory regime of the Basel II Accord is being especially criticized for its pro-cyclical effects, which are very actual to the less developed economies. The essence of the regulations caused problems is that it requires financial institutions to increase their capital ratios as the institutions encounter higher risks. Unfortunately, this leads to diminished lending, when it is most necessary, i.e. at economic slowdowns or crises, which only deepens their negative effects.

3 The best illustrating examples are the "Celtic Tiger" economic explosion period in Ireland in 1995-2008, the "Baltic Tigers" rapid economic growth period in Lithuania, Latvia and Estonia in 2000-2007) followed by deep recessions, continuing until now.
} 
increases (decreases) and government spending decreases (increases) in good (bad) times. The opposite direction to the business cycle will change government spending $(\mathrm{g})$ to GDP ratio since the government expenditure $(\mathrm{g})$ will decrease (increase) in good (bad) times. Generalizing, an economic or financial policy can be called counter-cyclical if it works against the cyclical tendencies in the economy. That is, counter-cyclical policies are ones that cool down the economy when it is in an upswing, and stimulate the economy when it is in a downturn.

A-cyclical fiscal policy occurs at a constant level of government spending and constant tax rates in various stages of business cycles (government spending and tax rates do not change with the business cycle). Such a policy is called acyclic, since it does not enhance or stabilize the business cycle (Kaminsky et al., 2004). Acyclic fiscal policy in the tax rate of the business cycle is constant and the tax base increases in good times and decreases in bad times, and thus correlation of income tax variable with the business cycle is positive. The ratio of government spending to GDP is negatively correlated with the business cycle, for a continuation of government spending, and grounding on the definition, the GDP is high (low) in good (bad) times (Kaminsky et al., 2004).

In the last decade of the twentieth century cyclical policy problems were subject to discussion in scientific literature in Gali (1994), Fiorito and Kollinz (1994) and Fiorito (1997), who found that government spending is contra-cyclical or acyclical in developed countries. This approach is also supported by Perotti (2003); Lane (2003); Kaminsky et.al. (2004) and Alesina, Tabellini (2005). In the scientific literature analysed, there is a strong consensus that governments of the less developed countries, have pro-cyclical policies. The scientific literature analysed proposes several perspectives of the less developed countries policy pro-cyclicality. The first approach relies on the financial market constraints (Gavin and Perotti (1997); Riascos and Vegh (2004)), the second - focuses on the political constraints (Talvi and Vegh (2005), Alesina and Tabellini (2005), Ilzetzki (2007).

So what kind of cyclical policy is most appropriate for a small open economy? The scientific literature on cyclical policies is mainly focused on Keynes theory representatives, who argue that fiscal policy needs to act as a stabilization tool and should be counter-cyclical. According to Karazijiene (2009), Kindsfateriene and Lukasevicius (2008), Lakstutiene (2008) in the period of the economic downturn, the government has to increase spending and reduce taxes in order to reduce the impact of the recession to the economy but during the economic boom - the government has to reduce government spending and raise taxes, i.e. carry out a damping fiscal policy.

Furthermore the Keynesian economists advocate the use of automatic and discretionary counter-cyclical policies to lessen the impact of the business cycle. One example of an automatically countercyclical fiscal policy is progressive taxation. By taxing a larger proportion of income when the economy expands, a progressive tax tends to decrease demand when the economy is booming, thus reining in the boom. Other schools of economic thought, such as monetarism and new classical macroeconomics, hold an opinion that countercyclical policies may be counterproductive or destabilizing, and therefore favour a laissez-faire policy as a better method for maintaining an overall robust economy. When the government adopts a counter cyclical fiscal policy in response to a threat of recession the government might increase the infrastructure spending.

The analysis of the scientific literature has also revealed that pro-cyclical fiscal policy is detrimental to the economy (Perotti, 2007; Woo, 2009), but with different restrictions in present governments of less developed countries are not able to carry out the counter-cyclical fiscal policies at the period of the economic downturn. Caballero and Krishnamurty (2004) indicate that on the onset of restrictions on credit markets, pro-cyclical fiscal policy changes must be made on the expenditure side, but not the tax side, i.e. government should reduce the public sector current expenditures, help firms in difficulty as much as possible. And also the governments of the less developed countries should as much as possible reduce the budget deficit in order to mitigate the effect of private investment outflows, which occurs much stronger in the period of the credit crisis.

\section{The relation between a pro-cyclical regulation and credit crisis}

The scientific literature analysed, proposes a unified approach that a pro-cyclical regulation (usually adopted by the less developed countries having no other options) generally leads to (or strengthens) the effects of the economic crisis, a part of which is a credit crisis, analysed in this paper. In general terms a credit crisis is a sudden loss of loans (or credits) accessibility or a tightening of the conditions required to get a credit from a financial institution. According to Gilchrist et al. (2009), in such situations, the relationship between credit availability and interest rates implicitly changes, so that either credit becomes less available at any given official interest rate, or there ceases to be a clear relationship between interest rates and credit availability.

As scholar Simkovic (2008) states, there are a number of reasons why banks might suddenly stop or slow the 
lending activity: for example, inadequate information about the financial condition of borrowers can lead to a boom in lending when financial institutions overestimate creditworthiness, while the sudden revelation of information suggesting that borrowers are or were less creditworthy can lead to a sudden contraction of credit. According to Lakstutiene, Breiteryte and Rumsaite (2009), Lakstutiene, Vasiliauskaite and Leitoniene (2006) causes of credits and loans congelation may include an anticipated decline in the value of the collateral used by the banks to secure the loans; an exogenous change in monetary conditions (for example, where the central bank suddenly and unexpectedly raises reserve requirements or imposes new regulatory constraints on lending); the central government imposing direct credit controls on the banking system; or even an increased perception of risk regarding the solvency of other banks within the banking system.

As stated by Rajan (2005) and Thoma (2010), a credit crisis is often caused by a sustained period of careless and inappropriate lending which results in losses for lending institutions and investors in debt when the loans turn sour and the full extent of bad debts becomes known. Careless lending tends to occur more often in fragmented, competitive credit markets in which lenders may compete with one another for market share and revenue by relaxing standards. However, by contrast, concentrated credit markets tend to have tighter standards and greater stability, states Simkovic (2011).

Financial institutions facing losses may then reduce the availability of credit, and increase the cost of accessing credit by raising interest rates. In some cases lenders may be unable to lend further, even if they wish, as a result of earlier losses.

The crisis is generally caused by a reduction in the market prices of previously "overinflated" assets and refers to the financial crises that result from the price collapse (Bank for International Settlements, 2000). This can result in widespread foreclosure or bankruptcy for those investors and entrepreneurs who came in late to the market, as the prices of previously inflated assets generally drop precipitously.

A prolonged credit crisis is the opposite of cheap, easy and plentiful lending practices (sometimes referred to as "easy money", "loose credit", or "malinvestment"). During the upward phase in the business cycle, asset prices may experience bouts of frenzied competitive, leveraged bidding, inducing inflation in a particular asset market. This can then cause a speculative price "bubble" to develop. As this upswing in new debt creation also increases the money supply and stimulates economic activity, this also tends to temporarily raise economic growth and employment (at the state of expansion), state Rowbotham (1998) and Cooper (2008). In the rapid growth periods described above, the role and correct actions of the countries governments are of crucial importance in escaping the pro-cyclical effects to the economy.

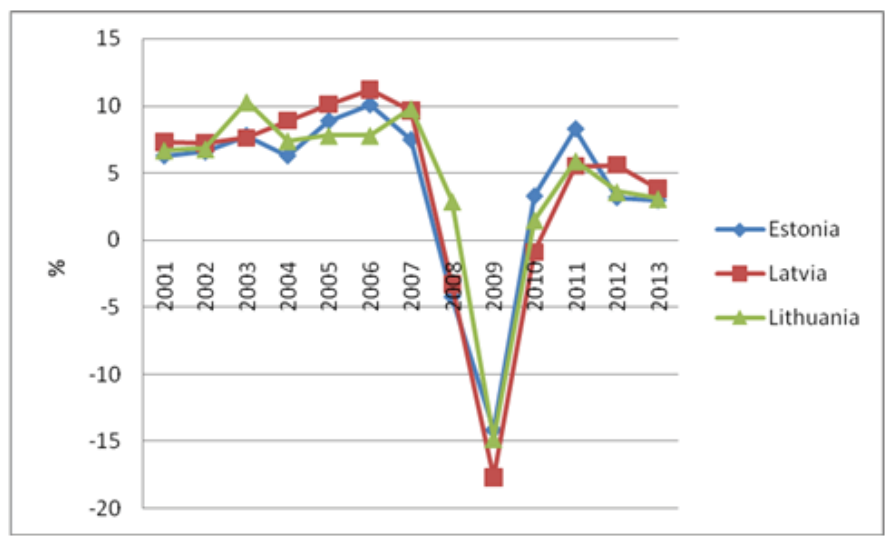

Figure 1. Annual GDP growth rate.

Source: data collected from Eurostat *2013 values are estimates

Figure 1 above illustrates the unableness of the three Baltic governments to mitigate the effects of the economic cycle in the context of annual GDP growth rate. The economic boom of 2004-2007 is followed by a damaging crash in 2009. Many pro-cyclical policies and actions have greatly contributed to the scope of the economic downturn. In the context of correct fiscal policy adoption by a small open economy, the Lithuanian case is (unfortunately) an example of what not to 
do. In 2007 due to the economic heating the temporary budget income was turned into the full budgetary costs and liabilities, i.e. 34.4 billion Litas government spending in 2007 rose to 41.6 billion Litas in 2008. The reserves were not collected nor from a surplus of income neither from other sources. On the basis of better than expected earnings the regularly reviewed mid-year budgets only increased spending. The Lithuanian Social insurance reserves fell from 1.9 billion Litas in 2007 to 0.6 billion Litas in 2008 and in December 2009 the Social Insurance deficit was fixed at 2.3 billion Litas. All this and pro-cyclical fiscal policies (Personal Income Tax cuts in 2008, failure to implement the real estate tax) not only created huge structural deficit, which "naked" at the disappearance of cyclical income, but continued heating up the economy by bursts of artificial demand. Observing other European countries situations, it is important to mention that there is a wide space of learning from them. Table 2 below illustrates the means employed by some of them to avoid the pro-cyclical effects and credit crises.

Table 2. Means employed by European countries to avoid the pro-cyclical effects and credit crises.

\begin{tabular}{|c|c|}
\hline United Kingdom & $\begin{array}{l}\text { On the basis of Constitutional laws in the period of the economic cycle the government seeks to } \\
\text { balance the budget in relation to the "golden rule." }\end{array}$ \\
\hline Germany & The Constitution requires a balanced budget by the national classification. \\
\hline Italy & $\begin{array}{l}\text { Both the Constitution and laws require municipalities to have a balanced budget in accordance } \\
\text { with the national classification. }\end{array}$ \\
\hline Poland & Both the Constitution and laws require not to exceed certain debt indicators. \\
\hline Austria & $\begin{array}{l}\text { The Constitution based laws require having a balanced municipal budget in a four-year period, in } \\
\text { accordance with the European System of Accounts ESA } 95 \text { classification. }\end{array}$ \\
\hline European Union & $\begin{array}{l}\text { The EU's founding Treaty and the Stability and Growth Pact require adherence to fiscal } \\
\text { discipline: seek to structurally balance the budget, prevent the threat to exceed } 3 \text { percent of GDP } \\
\text { fiscal deficit limit. It is noticeable, that the EU's founding treaty provides financial penalties and } \\
\text { sanctions for fiscal norms violations. }\end{array}$ \\
\hline
\end{tabular}

According to Simonyte 4 (2010), the European Commission for several years has tried to draw the Lithuanian authorities' attention to the fact that budgetary discipline Lithuania is not sufficient and that there should also be mandatory rules. However, if fiscal discipline is not the country's political culture, there is always the temptation to override the selfimposed rules. On the other hand, if fiscal discipline is the political culture, even without formal rules for it, the governments should be able to maintain good fiscal performance.

\section{The consequences of credit crisis in countries with pro-cyclical regulation}

Since the global economic crisis began in 2008 regions across the world at a smaller or larger extent are experiencing a credit crisis. The list of credit crisis consequences, analysed in scientific literature, is endless, however, depending on the size of the economy, and most important, the type of fiscal policy adopted, these consequences vary subsequently across countries. After carrying out an analysis of scientific literature and statistical data, it can be concluded, that the most essential consequences of the credit crisis in small open economies with pro-cyclical regulation are the following:

- congelation of all types of credits, difficulties for businesses to obtain credits;

- declining values in real estate and contraction of the whole construction sector;

- high loss of property rights (foreclosure) rates and default rates on credits;

- diminishing consumption of households and businesses;

- numerous close-downs of small and medium enterprises (SMEs);

- rise in unemployment;

- growing emigration, brain-drain and etc.

It is important to emphasize, that all the above mentioned consequences are interdependent and changes in one of them automatically affect the other ones. Firstly, with the emergence of the first signs of the economic crisis, and most economic indicators showing problems ahead, commercial banks have sharply diminished or even stopped issuing credits and loans. The most crucial consequences of it were felt in the construction sector.

${ }^{4}$ Ms. Simonyte was a minister of finance in Lithuania in the period of 2009-2012. 


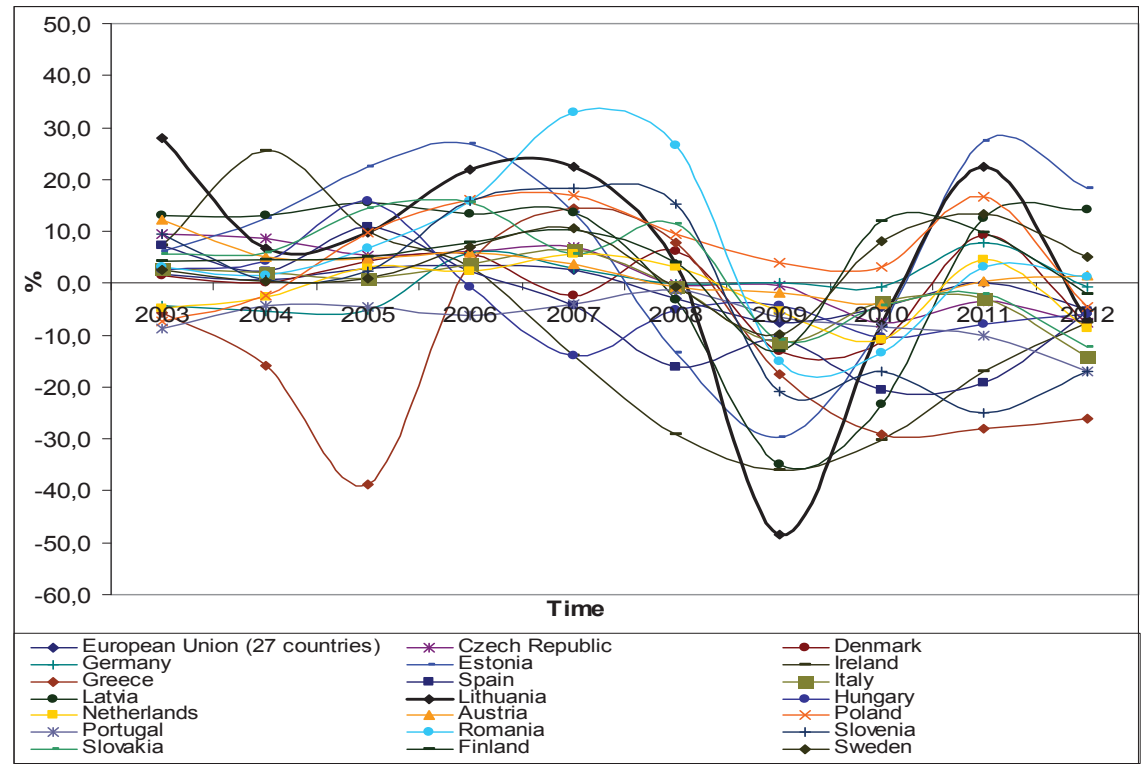

Figure 2. Dynamics of construction sector by country. Source: data collected from Eurostat

The Figure 2 above illustrates the effects of the credit crisis in construction sector in the context of the European countries. Looking at the year 2009, countries with a most pro-cyclical regulation can be easily singled out. Those include: Lithuania (lowest point), followed by Latvia, Estonia and Slovenia. ${ }^{5}$ The crash in the construction sector rapidly echoed to many connected economic sectors such as wood-processing, textiles, furniture and others and later were followed by high loss of property rights (foreclosure) rates and default rates on issued credits. This all resulted in numerous bankruptcies and close-downs of small and medium enterprises, sharply diminished consumption of households and businesses. Although the year 2011 has demonstrated a sharp increase in the real estate development again, the consequences of the crisis are still present.

One of the best illustrators of the overall state of the economy is the unemployment rate. Although, the economic crisis in most countries is reported to be at end in 2012, analysing the statistical data, it becomes clear that it is still present and, in some cases, deepening. Figure 3 reveals the unemployment trends in the European countries in the period of the last nine years. Countries with larger pro-cyclicality clearly outstand with sharp fluctuations. Excluding the extraordinary unemployment rates of Greece and Spain, the same triad of former Baltic tigers can be observed. It is important to mention, that the unemployment rates reflected in Figure 3 are strongly reduced by record high emigration rates. However, the reduction of the unemployment rates, and the abroad earned money sent back home ${ }^{6}$ are the only positive aspects about emigration.

\footnotetext{
${ }^{5}$ As proposed in the scientific litarature analysed while preparing this paper, the main causes for the real estate (or construction bubble) were failures of the governments to adopt property taxes, many investor privileges and unnecessary exemptions as well as irresponsible lending from commercial banks.

${ }^{6}$ In modern scientific litarature the abroad earned money transactions back home are welcomed as help to raise the domestic consumption, but on the other hand, blaimed for augmenting the pro-cyclical effects.
} 


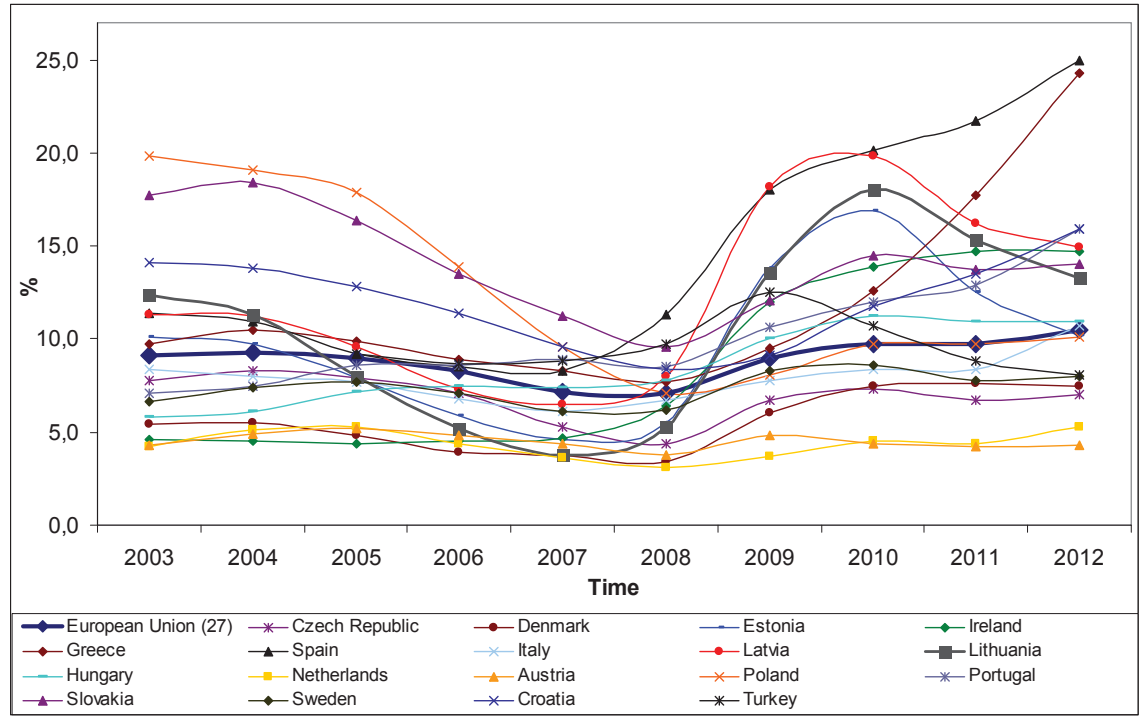

Figure 3. Unemployment trends by country. Source: data collected from Eurostat

The real consequences lie deeper and are much sadder. Concluding the scientific works of (Ohmae, 2005; Dally, 2004; Sipaviciene, 2006), emigration has particularly negative consequences for the countries business environment. First, most businesses immediately feel labor shortages and the loss of workers need to be replaced as soon as possible, but the process is often delayed, resulting in loss of funds and time. In addition, the large-scale emigration is a threat to smaller countries demographics, which in terms of business, is a reduction of the internal market, i.e. there are fewer consumers. Furthermore, two dangerous trends are observed in the period of the few past years. First, there is a sharp increase of high-skilled labor force emigration rates, and second, the less developed countries are starting to experience the brain drain to higher-wage countries problem. This results in weakening of their intellectual potential, slowing down of the technological progress as well as scientific and economic development, deterioration of development perspectives (especially in knowledge-intensive areas of the economy).

\section{Conclusions}

It is widely agreed that a proper fiscal policy adopted by a countries government should help in stabilizing the economy while maintaining the aggregate demand and private sector revenue during the economic downturn, and regulate the economic activity in periods of strong economic growth, i.e. control the outcomes of the business cycles. Unfortunately not all countries can (and do) adopt the counter-cyclical policy, described above. Due various political, social or most often economic constraints many less developed countries have a pro-cyclical policy. The most common effect of a procyclical policy adopted is sharp economic downturns resulting in credit crisis. The consequences of the latter vary across countries, but most common of them include the following: congelation of all types of credits, difficulties for businesses to obtain credits; declining values in real estate and contraction of the whole construction sector; high loss of property rights (foreclosure) rates and default rates on credits; diminishing consumption of households and businesses; numerous close-downs of small and medium enterprises (SMEs); rise in unemployment; growing emigration, brain-drain and etc. The analysis of the statistical data revealed that the more the countries policies are of pro-cyclical character the stronger the above mentioned effects are.

\section{References}

Abel, A., Bernanke, B. (2001). Macroeconomics, 4th edition. New York: Addison Wesley.

Alesina, A., ir Tabellini, G. (2005). Why is fiscal policy often pro-cyclical? NBER Working Paper, 11600.

Bank for International Settlements. (2000). Principles for the Management of Credit Risk. Available at: 
$<$ http://www. bis.org/publ/bcbs75.htm>.

Caballero, R., ir Krishnamurthy, A. (2004). Fiscal Policy and Financial Depth. NBER Working Paper, 10532.

Cooper, G. (2008). The Origin of Financial Crises. Harriman House. ISBN 1-905641-85.

Dally, E. Population, Migration, and Globalization. World Watch Magazine, 2004 vol.17, no. 5, p. 9-15.

Fiorito, R. (1997). Stylized facts of government finance in the G7. IMF Working Paper, No. 97/142.

Fiorito, R., ir Kollintz, T. (1994). Stylized Facts of Business Cycles in the G7 from a Real Business Cycles Perspective. European Economic Review, Vol. 38, No. 2, 235-269.

Gali, J., ir Perotti, R. (2003). Fiscal Policy and Monetary Integration in Europe. NBER Working Paper No. 9773.

Gavin, M., ir Perotti, R. (1997). "Fiscal Policy in Latin America". NBER Macroeconomics Annual, 11-61.

Gilchrist, S., Yankov, V., Zakrajšek, E. (2009). Credit Market Shocks and Economic Fluctuations: Evidence from Corporate Bond and Stock Markets. Journal of Monetary Economics, Elsevier, vol. 56(4).

Ilzetzki, E. (2007). Rent-Seeking Distortions and Fiscal Procyclicality. University of Maryland, manuscript, May.

Kaminsky, G.L., Reinhart, C.M., Vegh, C.A. (2004). When It Rains It Pours: Procyclical Capital Flows and Macroeconomic Policies. NBER Working Paper 10780.

Karazijiene, Z. (2009). Modelling of the Effect of the Public Sector Borrowing on the Lithuanian Economy. Inzinerine EkonomikaEngineering Economics(4), 24-31.

Kindsfateriene, K., \& Lukasevicius, K. (2008). The Impact of the Tax System on Business Environment. Inzinerine EkonomikaEngineering Economics (2), 70-77.

Lakstutiene, A. (2008). Correlation of the Indicators of the Financial System and Gross Domestic Product in European Union Countries. Inzinerine Ekonomika-Engineering Economics(3), 7-18.

Lakstutiene, A., Breiteryte, A., \& Rumsaite, D. (2009). Stress Testing of Credit Risk Lithuania Banks under Simulated Economical Crisis Environment Conditions. Inzinerine Ekonomika-Engineering Economics(5), 15-24.

Lakstutiene, A., Vasiliauskaite, A., \& Leitoniene, S. (2006). Dependence of the Financial Structure and Efficiency of the Bank Sector on Economic Growth. Inzinerine Ekonomika-Engineering Economics (3), 18-27.

Lane, P.R. (2003) The Cyclical Behaviour of Fiscal Policy: evidence from the OECD. Journal of Public Economics 87, $2661-2675$.

Ohmae, K. (2005). The Next Global Stage: Challenges and Opportunities in our Borderless World. London: Wharton Publishing.

Perotti, R. (2007). Fiscal Policy in Developing countries: A Framework and Some Questions. World Bank Policy Research Working Paper, WPS4365.

Rajan, R.G. (2005). Has Financial Development Made the World Riskier? Available at: http://www.kc.frb.org/publicat/sympos/2005/PDF/Rajan2005.pdf

Riascos, A., ir Vegh, C.A. (2004). Procyclical Fiscal Policy in Developing Countries: The Role of Capital Market Imperfections. IMF Staff Papers.

Rowbotham, M. (1998). The Grip of Death: A Study of Modern Money, Debt Slavery and Destructive Economics. Jon Carpenter Publishing. ISBN 978-1-897766-40-8.

Simkovic, Michael, Competition and Crisis in Mortgage Securitization (October 8, 2011). Indiana Law Journal, Vol. 88, p.213, (2013). Available at SSRN: http://ssrn.com/abstract=1924831 or http://dx.doi.org/10.2139/ssrn.1924831.

Simkovic, Michael, Secret Liens and the Financial Crisis of 2008 (January 4, 2009). American Bankruptcy Law Journal, Vol. 83, p. 253, 2009. Available at SSRN: http://ssrn.com/abstract=1323190.

Simonyte, I. (2010). Budget System Reform. Lithuanian Ministry of Finance.

Sipaviciene, A. (2006). International migration of Lithuanians: change of the model and situation analysis: a monograph.

Talvi, E., ir Vegh, C.A. (2005). Tax Base Variability and Pro-cyclical Fiscal Policy in Developing Countries. Journal of development Economics 78, 156-90.

Thoma, M. (2010). Leverage cycles. Available at: http://economistsview.typepad.com/economistsview/2010/01/leverage-cycles.html.

Woo, J. (2009). Why Do More Polarized Countries Run More Pro-cyclical Fiscal Policy? The Review of Economics and Statistics Vol. 91 , No. 4, 850-870. 